Safundi

\title{
Zanele Muholi's Intimate Archive: Photography and Post-apartheid Lesbian Lives
}

\section{Kylie Thomas}

To cite this article: Kylie Thomas (2010) Zanele Muholi's Intimate Archive: Photography and Post-apartheid Lesbian Lives, Safundi, 11:4, 421-436, DOI: 10.1080/17533171.2010.511792

To link to this article: http://dx.doi.org/10.1080/17533171.2010.511792

曲 Published online: 23 Sep 2010.

Submit your article to this journal ¿

Lll Article views: 1372

Q View related articles $\longleftarrow$

Citing articles: 10 View citing articles 4 


\title{
Zanele Muholi's Intimate Archive: Photography and Post-apartheid Lesbian Lives
}

\author{
Kylie Thomas
}

The ones who fear me think they know who I am.

$$
\text { Minnie Bruce Pratt }{ }^{1}
$$

This paper focuses on the work of South African black lesbian photographer Zanele Muholi and raises the question of how experience that is deemed unspeakable can enter representation. If we always read images through "codes of connotation," through what Roland Barthes terms the "studium" of our knowing, how is it possible to overturn ways of seeing that render lesbian subjectivity invisible? ${ }^{2}$ And if lesbian subjectivity is made visible through suspending the structures of recognition, what are the political implications of occupying such an "outlaw" position? How does being beyond recognition open or close the field of political possibility? The paper makes two theoretical claims: one, that Barthes' influential concept of the "punctum" can be understood as a mode of queer reading, and two, that Muholi's work constructs an archive that insists on the specificity of lesbian lives and loss through a complex strategy of "passing." My reading of Muholi's portraits that constitute her "Faces and Phases" series explores how her photographs work with the ambiguities of "passing"- passing away, passing between states of gendered being, and passing through the prohibitions against making lesbian experience visible and mourning lesbian loss. In this way, the paper argues that Muholi's most recent body of work "queers" both the conventions of memorial photography and her own earlier representations of lesbian subjectivity.

Correspondence to: Kylie Thomas, Post-doctoral Research Fellow, Archive and Public Culture Research Initiative, Department of Social Anthropology, University of Cape Town, Private Bag, Rondebosch 7701, South Africa. Email: kylie.thomas@uct.ac.za

\footnotetext{
${ }^{1}$ Pratt, Crime Against Nature, 114.

${ }^{2}$ Barthes, Camera Lucida, 26.
} 


\section{K. Thomas}

Zanele Muholi is one of a handful of black women artists who figure prominently in the visual art field and her work has been shown both in South Africa and abroad. She is certainly the most visible black lesbian artist in South Africa and has received numerous awards for her work. Her photographs have also generated a great deal of controversy. In August 2009, South Africa's Minister of Arts and Culture, Lulu Xingwana, walked out of an exhibition that contained several of Muholi's photographs on the grounds that they were "immoral, offensive" and worked "against nation-building." 3 This has placed Muholi's photographs at the center of a national debate about homophobia, freedom of expression, and queer experience. ${ }^{4}$ I will return to the significance of Xingwana's comments later in this paper in my discussion of the tactics Muholi employs in her photographs of black lesbians who have been subject to "corrective rape" and who have died of AIDS-related causes, or who were murdered as a result of hate crimes. I read these images as works of mourning that invoke conventional tropes of memorialization to circumvent precisely the socially normative prohibitions so dramatically performed by Xingwana in her role as an authorized voice of the state. The paper offers an analysis of the transformation in Muholi's mode of working that occurs when she addresses the question of how to represent loss. In particular I trace how her current work draws on the conventions of memorial photography in order to secure a place for queer subjects within representation.

At the same time, I show how this complex working with and against the "structures of recognition" signals a departure from her earlier and more narrow conceptualizations of lesbian subjectivity. ${ }^{5}$ In order to do this, I begin by describing some of the ways in which her photographs can be understood as engaged in the task of "differencing the canon," before turning to a reading of her most recent series of portraits, "Faces and Phases." The work of South African feminist theorists Desiree Lewis and Pumla Dineo Gqola and curator and artist Gabi Ngcobo has drawn attention to how Muholi's photographs render visible the complexity of lesbian lives. ${ }^{6}$ However, this brave and politically necessary task is not the sum of her work. The import of her current photographs lies in how they both lay bare and contest the ways in which the lives of queer subjects are made invisible and their deaths ungrievable. "Faces and Phases," I argue here, works at the limit of the speakable, and Muholi's photographs mark that limit even as they pass beyond it.

\footnotetext{
${ }^{3}$ Van Wyk, "Xingwana." For the media statement issued by Xingwana, see her "Statement" online. It is also instructive to read the Minister's statements on art that does promote nation-building. See, for instance, her address at the launch of the "Moral Regeneration Month" in July 2009: Xingwana, "Address by the Minister of Arts and Culture."

${ }^{4}$ I employ the term "queer" to open a way of thinking about sexuality and subjectivity that crosses and seeks to undo the bounds between categories of identification such as "gay," "lesbian," "straight," "bisexual," and "intersex."

${ }^{5}$ I draw the phrase "structures of recognition" from psychoanalytic theorist Parveen Adams. The term implies socially constructed ways of seeing and modes by which one becomes recognizable as a subject, as well as the psychic dimension of the operations of the gaze. See Adams, Emptiness of the Image.

"See Lewis, "Against the Grain"; Gqola, "Through Zanele Muholi’s Eyes"; and Ngcobo, "Introduction."
} 


\section{DisRUPTING VISUAL CODES}

In Encounters in the Virtual Feminist Museum, Griselda Pollock presents an approach to the history of art that embarks on the work of what she terms "differencing the canon." She swiftly lays to rest the notion that the canon is quite "differenced" enough already by noting that "[n] ot only have we had to struggle and still struggle on to ensure equity in the representation of all women as well as all men in our cultural archives, but now our very struggle is being written out of history, brushed off as a passing irritant." ${ }^{\prime 8}$ Pollock begins her reflections on the place of women in the history of art, in the museum and in the archive, by relating her encounter with a series of postcards that depict The Three Graces, a neo-classical sculpture by Antonio Canova. She notes how the prevalence of the female nude in the art museum is so naturalized that we no longer see its strangeness, and as longstanding signifier of Western art the naked female form becomes a placeholder for women in art-the place of "woman" in the museum, a stony limit point for feminist art practice and theory. Her book goes on to produce "a virtual feminist museum" through a constellation of images exhibited in what she terms "rooms" at the beginning of each of her chapters, all of which unsettle and recalibrate the archive of art history. Pollock's work reminds us that "Archives matter. What is included shapes forever what we think we were and hence what we might become. The absence of women's histories in world archives has defined a vision of the human on the pattern of a privileged masculinity." "9 Pollock's approach to reconfiguring how we think about visual culture is suggestive, and her archival feminist aim resonates with the work of Zanele Muholi in several ways. Muholi's project is also an archival one and is concerned with many of the same issues of visibility and invisibility that have consumed feminist scholarship since the 1970s. In her artist's statement that appears in the catalogue for the "Innovative Women" exhibition, she writes: "As an insider within the black lesbian community and a visual activist, I want to ensure that my community, especially those lesbian women who come from the marginalised townships, are included in the women's 'canon."'10

A cursory survey of Muholi's work thus far reveals the intensity of her commitment to producing a visual archive of black lesbian experience. Her photographs have appeared in group exhibitions since 2002; her solo exhibition Visual Sexuality was held at the Johannesburg Art Gallery in 2004; and since 2006, she has been represented by Michael Stevenson, a commercial art gallery in South Africa. She has held four additional solo exhibitions there: Only Half the Picture (2006); Being (2007); Faces and Phases, first exhibited as a series in 2009; and Indawo Yami (2010). Her exhibitions in Europe and North America include solo shows in Vienna and Amsterdam. In 2007, together with white South African lesbian photographer Jean Brundrit, Muholi facilitated a series of photographic workshops "to gather

\footnotetext{
${ }^{7}$ Pollock, Encounters, 13. See also Pollock, Differencing the Canon.

${ }^{8}$ Pollock, Encounters, 13.

${ }^{9}$ Ibid., 12.

${ }^{10}$ Van Wyk, "Xingwana."
} 


\section{K. Thomas}

diverse opinions and diverse lesbian experiences in South Africa" with eight aspiring photographers. ${ }^{11}$ While the artist is now firmly positioned within the commercial art world, she continues her work with the Forum for the Empowerment of Women, an organization that she co-founded, and to teach others to take photographs. ${ }^{12}$ As this paper shows, the bounds of her photographic archive have expanded to include representations of multiple forms of queer subjectivity.

Muholi's photographs open new spaces of representation in South African visual culture, but follow in the tradition of feminist/lesbian art-making practices established over time by artists such as the US-based Judy Chicago, Cindy Sherman, Laura Aguilar and others. In her oeuvre there are numerous works that proclaim their transgressive, disruptive stance, and these are perhaps the images that are easiest to categorize, easiest to dismiss—as some critics have-as "not very good art" that nonetheless makes an important political point. ${ }^{13}$ Some of the images in Muholi's book Only Half the Picture and some that appear in her more recent "Being" series are among those that invoke conventional tropes of lesbian/feminist representation to contest the bounds of what is considered proper for women and for art. "Dada, 2003," a black-and-white photograph of a bare-breasted black woman strapping on a dildo, her face beyond the frame of the image, the 2005-6 "Period" series, and the 2009 "LiZa" series can all be read as testing the limits of propriety in art and as a straightforward claiming of a visual space for embodied black lesbian experience. And through these works Muholi's project can be said to be aligned with the mainstream feminist position that Pollock articulates in Encounters in the Virtual Feminist Museum. For in this conceptualization of the production of a new form of feminist archive that makes the experiences of women visible, it is of course necessary that the women who are represented are recognizable as women. Muholi's project, one that she articulates on her website as "mapping and archiving a visual history of black lesbians in post-Apartheid South Africa," also engages and affirms a particular form of identity politics in order to lay claim to a place within an existing order of representation.

At the same time, Muholi's concern with securing a place for lesbian experience within "the women's 'canon"” signals that what constitutes lesbian subjectivity is by no means decided. Her words testify to the ontological insecurity of the category of being that is "lesbian" in a context where "corrective rape" is practiced as way to "restore" lesbians to womanhood. Bringing the work of Zanele Muholi into conversation with the feminist position that Pollock articulates also opens a way to consider what the limits of "differencing the canon" might be. What happens when radical and disruptive forms of subjectivity seek to enter representation? Does the canon hold? Does the archive seize up, prohibit entry? What kinds of silences remain?

\footnotetext{
${ }^{11}$ A selection of photographs by the participants at the workshop, a description of the project and some of Jean Brundrit's own very interesting photographic work-which, like Muholi's, engages with lesbian experience, (in)visibility and the archive-is collected in Brundrit, "A Lesbian Story."

${ }^{12}$ For more information about Muholi's visual activism, see her projects on her website www.zanelemuholi.com.

${ }^{13}$ See the critiques leveled at Muholi's early work by reviewers such as Smith, and reprinted in Muholi's Only Half the Picture, 2006, 90-1; and Hogg, cited in Lewis, "Against the Grain," 17.
} 


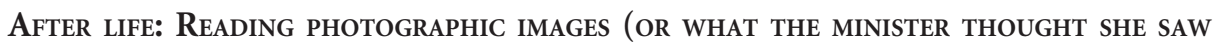
AT THE SHOW)

$[\mathrm{P}]$ hotographic connotation, like every well structured signification, is an institutional activity; in relation to society overall, its function is to integrate man, to reassure him.

Roland Barthes ${ }^{14}$

In August last year, I was invited to speak at the Innovative Women Art Exhibition at Constitution Hill. Upon arrival at the Exhibition, I immediately saw images which I deemed offensive. The images in large frames were of naked bodies presumably involved in sexual acts. I was particularly revolted by an image called "Self-rape," depicting a sexual act with a nature scene as backdrop. The notion of self-rape trivialises the scourge of rape in this country. To my mind, these were not works of arts [sic] but crude misrepresentations of women (both black and white) masquerading as artworks rather than engaged in questioning or interrogatingwhich I believe is what art is about. Those particular works of art stereotyped black women.

Lulu Xingwana ${ }^{15}$

In response to criticism that her departure from the show was homophobic, the Minister of Arts and Culture stated: "Contrary to media reports, I was not even aware as to whether the 'bodies' in the images were of men or women or both for that matter." 16 There is a strange way in which Xingwana's comments can be read as particularly insightful: Muholi's photographs do trouble the distinctions between men, women, "or both for that matter," and there is a powerful sense in which lesbians can only enter recognizable representation as "crude misrepresentations of women masquerading as artworks." Xingwana's act of turning away from the exhibition, her inability to look, also speaks to how certain images might serve to challenge and even overturn the conventions that govern our gaze. Her statements also reveal more than they intend about the challenges we find when we attempt to describe what it is we see, and in particular when we try to read a photograph. For what emerges is that while Xingwana found herself powerfully affected by her brief immersion in the field of black lesbian visual art, she did not see what she describes, nor is she quite sure of what it was she saw.

In her now classic work, On Photography, Susan Sontag explores the ubiquity and importance of photographic images in the industrialized countries of the West, where, she argues, life can no longer be imagined without cameras to provide evidence of life itself and people "feel that they are images, and are made real by photographs."17 Sontag's reflections on the symbolic power that photographic images have come to hold in contemporary society can also be read as an attempt to make sense of photography, to provide an answer to the question: "What is a photograph?" "The photographer both loots and preserves, denounces

\footnotetext{
${ }^{14}$ Barthes, Image, Music, Text, 31.

${ }^{15}$ Xingwana, "Statement."

${ }^{16}$ Ibid.

${ }^{17}$ Sontag, On Photography, 161.
} 
and consecrates," 18 she writes, and although "there is a sense in which the camera does indeed capture reality, not just interpret it, photographs are as much an interpretation of the world as paintings and drawings are."19

While for Sontag, the "force of a photograph is that it keeps open to scrutiny instants which the normal flow of time immediately replaces," for Roland Barthes the photographic image is no more outside of time than those who view it. ${ }^{20}$ For Barthes, photographs do not "capture" a moment of the real to be seen again and again, but in responding to the image, it is the viewer, and the society of which they are part, that is laid open to scrutiny. The instant in time the photograph is intended to capture is perceived afterwards; and it is in this after-time that the significance of the image comes to be constituted. In this sense, photographs do not preserve life but instead create it, a perpetual after-life. And it is in this making that the critical project of constructing a photographic archive of queer experience lies; an archive that testifies to the presence of black lesbians in the past, but also one that asserts and ensures their presence in the future.

In his essay "The Photographic Message," Barthes extends and complicates Sontag's definition of photographs and her analysis of how they can be read. He begins his essay with what he terms "the photographic paradox": "analogical perfection," the absence of a code that translates the object into its image, defines the photograph, which, at the same time, is a sign of something other than itself. The photograph appears to be "a mechanical analogue of reality," a "denoted message," and to describe it is to attach to the image a "connoted message, which is the manner in which the society to a certain extent communicates what it thinks of it."21

In front of a photograph, the feeling of "denotation," or, if one prefers, of analogical plenitude, is so great that the description of a photograph is literally impossible; to describe consists precisely in joining to the denoted message a relay or second-order message derived from a code which is that of language and constituting in relation to the photographic analogue, however much care one takes to be exact, a connotation: to describe is thus not simply to be imprecise or incomplete, it is to change structures, to signify something different to what is shown. ${ }^{22}$

For Barthes, then, a photograph is, and can only be, our reading of it. When we describe what we see, we "signify something different to what is shown." And crucially, how one reads is through other images, visible or remembered, alongside and in conjunction with the single image that can never be singular.

In Camera Lucida, Barthes extends his thinking about how photographs are read through the concepts of the "studium" and the "punctum." Most photographs belong to the studium, that which I have learned to see by acculturation and that which cannot really reach me. And then there are those photographs that arrest my gaze,

\footnotetext{
${ }^{18}$ Ibid., 64-5.

${ }^{19}$ Ibid., 6-7.

${ }^{20}$ Ibid., 112.

${ }^{21}$ Barthes, Image, Music, Text, 16-18.

${ }^{22}$ Ibid., 18-19.
} 
photographs that disturb the studium of my knowing, photographs that wound me, photographs that I love. This element within the photograph is animated through the particularity of my gaze. It is this that Barthes terms the "punctum": "The second element will break or (punctuate) the studium. This time it is not I who seek it out (as I invest the field of the studium with my sovereign consciousness), it is this element which rises from the scene, shoots out of it like an arrow, and pierces me."23 Again, we are reminded of Barthes' key insight that there is nothing really internal to the image: I read everything I see, and can only see what I read. This is not to disavow the relationship between myself and the image-the image wields a certain power by virtue of what it draws out in me. But as I look, the image becomes what I turn it into: my reading structures the image; I make it mean.

Barthes' concepts of the studium and the punctum set up a method of reading photographs that illuminates how all readings are cultural-but at the same time legitimate a deeply subjective mode of response. The concept of the punctum allows Barthes (not to mention all those who have followed in his wake) to cast his emotional, poetic responses to photographs as a theory. I draw on these concepts here to grant a kind of legitimacy to my readings of Muholi's photographs. At the same time, I am struck by how thinking of her work in relation to Barthes' influential terms casts light on the implications of "queering the gaze" beyond gay and lesbian studies. In other words, it is not simply that Barthes' method offers a productive mode of reading Muholi's photographs, but Muholi's work shows that reading with and for the punctum can be understood as a mode of queer reading, an openness to ways of seeing that disrupt the heteronormative patriarchal hegemony that limits and structures our gaze.

In Camera Lucida, Barthes writes of how "to give examples of punctum is, in a certain fashion, to give myself up." 24 To reveal the ways in which I am affected by a photograph is to be exposed, describing what I see is an act that "outs" me, one that positions my intimate self in a public sphere. "Giving myself up" before a photograph is also to occupy a subject position beyond or outside of my own. Faced with Muholi's portrait of Nomonde Mbusi, for example, I know that I have been set up to see in a certain way-this is the photographer's art. As with so many of her photographs, I face a beautiful image of a beautiful woman. ${ }^{25}$ The lines of this young woman's body are carved in light and are accentuated by the dark cloth behind her. Her head is wrapped in a scarf so that only the faintest trace of her hair is visible on her forehead. She appears to be moving towards the viewer; it seems she is about to speak. She is not wearing a shirt, but the photograph is cropped above her breasts. The smooth open expanse of her skin and her wide eyes are a form of invitation-an erotic photograph. The photographic encounter frames my desire-I want to see this woman, to hold her with my gaze. And yet she holds me; a kind of Mona Lisa effect comes into play; she seems to move as I do. To be interpellated by Nomonde Mbusi's

\footnotetext{
${ }^{23}$ Barthes, Camera Lucida, 26.

${ }^{24}$ Ibid., 43.

${ }^{25}$ The image can be viewed online. See Muholi, "Faces and Phases."
} 
eyes in this way is both liberating and disturbing. "Seeing" Muholi's photographs is premised on the notion that exchanging queer looks and recognizing the desire they conjure is to acknowledge the queerness inside ourselves.

What might the Minister have seen had she stayed to look at Muholi's photographs? The incendiary quality of the works Xingwana did and did not see lies in how they make possible a space for us to acknowledge our own (queer) desire, I want to argue, in how they provide an entry point into an intimate archive-one that is embodied, one that is formed through love. Xingwana's inability to look returns us to the question of how Muholi's representations of lesbian subjectivity alert us to the limit of the speakable even as they pass beyond it.

\section{LIGHT WRITING IN DARK TIMES}

Muholi's first monograph, Only Half the Picture, carefully works with the aesthetics of the body, a complex holding of traumatic histories encoded in skin together with a celebration of lesbian desire and the promise of pleasure. Through Muholi's lens, black female bodies are re-signified: framed as the subjects of and for lesbian desire, they make visible an erotics of longing, of sexual intimacy and of community. At the same time, many of the photographs carry resonances of images of black female bodies drawn from a long history of racist iconography and which map the continuities of black female oppression over time. In the cracked toenails of the women in "Triple III," for instance, there are signs of hardship; in the dark markings along the outer edges of the thighs of the reclining figures there is a shadow of darkness, of violence, bruises or stains. ${ }^{26}$ Read in conjunction with the other photographs in the "Triple" series that portray the interlocking legs and buttocks of three women and that bring to mind the erotic nudes of Edward Weston or Imogen Cunningham, the ambiguities of "Triple III" are largely erased. Its erotic dimension comes to the fore. The pose of the three women speaks of the stillness of sleep and shows the protective tenderness of bodies curved around one another.

And yet there is something disturbing about the arrangement of these bodies on the floor. They are shown to be resting on a strip of carpet, its detail in the foreground so close-up it becomes a strange terrain and then fades to merge with what appears to be a stone floor that extends behind them. The marks on the limbs of these women evoke the history of slavery, summon photographs of the bodies of those killed in the Rwandan genocide, provide a visual echo of the legs of school-girls who have been tear-gassed and who run from the police in Soweto in South Africa in 1976. The larger context of Muholi's book, one that includes photographs of women after being raped, raises the question of how it is possible to read black lesbian desire outside of the violence of both the past and present. I want to say that inside the frame of "Triple III" there is no fear, only kinship, intimacy, love. But if this is so, then fear is just beyond the borders of what is made visible here and haunts this

\footnotetext{
${ }^{26}$ The image can be seen on the Michael Stevenson Gallery website; see Muholi, "Only Half the Picture: 29 March-29 April 2006."
} 
beautiful assemblage of bare forms. Here, as in the works that form part of her series portraying lesbians who have been subject to hate crimes that I discuss below, Muholi is masterful in her portrayal of the vulnerability of the human body and the complexity of embodied experience.

In "Ordeal, 2003," there is a line of fury that runs through the arm of the woman who crouches at the edge of an enamel basin scrubbing her hands into a blurred frenzy, moving so fast and so slick with water they appear unskinned. ${ }^{27}$ At the center of the photograph in which everything else remains still, these hands are rendered unrecognizable, a pulpy mass, an internal organ exposed to the air, an aborted fetus or placenta. Something that cannot be washed clean.

This is the first of a series of photographs in Only Half the Picture that depicts the survivors of hate crimes. It is followed by a double-page spread of a case number, a crumpled piece of lined paper depicted against a black ground, issued by the South African Police Service in Meadowlands, Soweto. Handwritten on the page are the details of a case-the date of the incident, the name of the inspector assigned to the case, a phone number and an official stamp. There is also a line that reads "ATT. Rape + Assault GBH" [grievous bodily harm]. The photograph that appears overleaf casts light on why this hastily written case number should be accorded so much space. "Hate Crime Survivor I, 2004" is a closely cropped portrait of a woman visible from her waist to just above her knees. The vertical lines of her hospital-issue pajama pants angle slightly in towards the center of the photograph and draw the viewer's eyes to her slender wrists and hands which are positioned on her lap, her curved finger and thumb forming a dark hollow, a point of entry into her body, a metonym for the violated parts of her we cannot see. Around her wrists are three identificatory tags that signify her inpatient status but here also read as manacles, handcuffs. And suddenly her striped clothing resembles a prison uniform, and the posture of her body holds the echo of countless images of incarcerated men who stand with their heads bent, their hands and feet bound-a stance of guilt.

The implication is that in spite of the indisputable archival evidence represented by the photograph of the case number that immediately precedes this image, lesbians who are raped are often not believed and are treated as criminals both inside and outside of the justice system. The juxtaposition of these two photographs makes visible the ways in which those who are subject to rape are also often accused of having brought violence on themselves. The concept of "corrective" or "curative" rape is often read as premised on the idea that lesbians have done something wrong to begin with and that rape is that which will set things right, restoring "the natural order." Muholi articulates how rape is used to punish and "correct" lesbians in South Africa: "Curative rapes, as they are called, are perpetrated against us in order to make us into 'real' and 'true' African women-appropriately feminine, mothers, men's property." 28 Yet as Muholi's photographs show, understanding the psychic mechanism that underlies curative rape as an act that restores the order of patriarchy

\footnotetext{
${ }^{27}$ See this and other images at Muholi, "Only Half the Picture: 29 March-29 April 2006."

${ }^{28}$ Muholi, "Mapping Our Histories," 19.
} 


\section{K. Thomas}

through affirming relations of power between men and women is to grant a kind of sense to senseless acts of hate. Her series depicting survivors of hate crimes shows how the act of "curative rape" is fundamentally tied to a desire to murder.

One of the most painful photographs in Muholi's oeuvre is "Hate Crime Survivor II." It appears alongside the photograph of the "criminal/survivor" and powerfully undoes the flawed and fatal logic that seeks to blame lesbians who are raped. In a hospital ward on a high bed covered with a white sheet is a figure under a heap of dark bedclothes. In fact it is only the caption that accompanies the photograph which renders the figure legible-without the single line that tells us that what we are looking at is a person, a "survivor," there is no way to know for certain that the shape on the bed is a human form. The camera angle renders the bed enormous and foreshortens the figure so that the person appears shrunken, barely there. The photograph portrays how the human form is overcome by the trauma of psychic collapse. Here the effect of rape is shown to be ontological erasure, the annihilation of subjectivity. The person who we know to be there but that we cannot see has not been made "woman," but has been altogether unmade as a subject.

"Aftermath, 2004" portrays a woman standing, and in this sense contrasts the collapsed figure on the hospital bed on the preceding page. ${ }^{29}$ However, the large scar that extends down the length of this woman's thigh signifies that there can be no easy moving beyond the trauma of rape. The scar is a sign of a much older wound, but serves here as an outer manifestation of her more recent physical and psychic wounding through "corrective rape." The scar itself, an elongated teardrop, an opening into her body now closed, like the curled hand of the woman depicted in "Hate Crime Survivor I," serves as a metonym for her violated vagina. There is something unbearable about the positioning of this woman's hands. They seek to shield her, to protect her, in this instance from our gaze as much as from the traumatic memory of attack; but at the same time they are passive, they are hands that speak a history of defeat. If there is a punctum here, it is not the scar-which we cannot fail to see-but the light as it catches the thumb of this woman, her curled fingers, the vulnerability of her being that is encoded in her hands.

Muholi's hate-crimes series asks us to think differently about how we understand sexuality and subjectivity, and this is not restricted to thinking what lesbians are or might be. They show us that to be lesbian is not to perform desire in a way that transforms/queers an underlying essential being that is "woman." Instead they show, through laying bare the painful way in which the corrective rape of lesbians restores absolutely nothing at all, the emptiness at the center of the fiction that animates all forms of gendered being. ${ }^{30}$

\footnotetext{
${ }^{29}$ For other readings of this photograph see Lewis, “Against the Grain,” and Gunkel, Cultural Politics.

${ }^{30}$ The key text for thinking gender as performative remains Judith Butler's Gender Trouble, which asks, among other things, how "language itself produce[s] the fictive construction of 'sex"' (xi).
} 


\section{QUEERING THE ARCHIVE}

The ways in which Antonio Canova's sculpture of the Three Graces might be read as pregnant with lesbian/transsexual desire is surfaced in a photographic work by British artist Della Grace/Del LaGrace Volcano. ${ }^{31}$ The black-and-white photograph shows three women, naked but for their jackboots, standing in the pose of The Three Graces with their arms around one another and their heads shaved, their bodies scarified, pierced and tattooed. I first saw LaGrace Volcano's reworking of the sculpture in Parveen Adams' book The Emptiness of the Image, and Adams' reading of the photograph is a provocative one. For Adams, the image disturbs the conventional modes of representation of woman to such an extent that she argues: "These women are beyond recognition." ${ }^{\text {"32 }}$ She goes on to explain:

Recognition is a process that may be looked at from two sides. Women who are recognized as such are recognized by a rigorous template of definition. If we do not recognize, in this photograph, these women, it is not because they are recognized as something else. It is rather because the structure of recognition has been suspended. ${ }^{33}$

What Adams draws attention to here is the way in which LaGrace Volcano's photograph inaugurates a way of looking that undoes our gendered gaze. The transgressive power of the image lies in the fact that we cannot simply substitute "woman" for another recognizable category of being - whether that is "lesbian" or anything else. Adams' reading provides a way to account for the absence of LaGrace Volcano's The Three Graces from Pollock's virtual feminist museum. Her analysis of how the photograph works to suspend the structures of recognition raises the question of what it means to be positioned outside the realms of the legible. And this returns us to the significance of the archive, which, as Pollock notes,

is pre-selected in ways that reflect what each culture considered worth storing and remembering, skewing historical record and indeed historical writing towards the privileged, the powerful, the political, military and religious. Vast areas of social life and huge numbers of people hardly exist, according to the archive. The archive is overdetermined by facts of class, race, gender, sexuality and above all power. ${ }^{34}$

Indeed, the archive produces these "facts" as much as it holds them and seeks to secure them. The archive is also (and I think this is the sense in which Zanele Muholi employs the term) a site of struggle for legitimacy. A certain kind of entry into the archive will mark queer lives as deviant, perverse, and criminal. Another mode of entry, one that Muholi's work seeks to find, is that which will guarantee visibility within the social that is not at the same time a form of erasure. Central here is the question of what the archive itself demands: what are the conditions of entry into the archive of legibility? If "the archive is the law of what can be said," then what is

\footnotetext{
${ }^{31}$ Della Grace is now Del LaGrace Volcano, a gender-variant visual artist. See www.dellagracevolcano.com.

${ }^{32}$ Adams, Emptiness of the Image, 123.

${ }^{33}$ Ibid., 138.

${ }^{34}$ Pollock, Encounters, 12 (my italics).
} 


\section{K. Thomas}

the place of outlaw subjects who are not merely beyond or outside the law, but who signify the law's very undoing ? $^{35}$

It is in a space of suspension, a kind of limit zone between recognition and invisibility, that Muholi's most powerful photographs are situated. The ways in which Muholi carefully forces the boundaries of the archive's frontier is the subject of the remainder of this paper. I explore how, through a process that literary theorist Ross Chambers terms "genre-hijacking" 36 and that I draw on and recode here as "passing," Muholi's work performs a complex negotiation of the limits and possibilities of and for queer subjectivity within representation. ${ }^{37}$

\section{MOURNING AND/AS MASQUERADE}

Ultimately, Photography is subversive not when it frightens, when it repels, or even stigmatizes, but when it is pensive, when it thinks.

$$
\text { Roland Barthes }{ }^{38}
$$

There is a second punctum that Barthes identifies as he studies the photographs that move him and attempts to identify the secrets of photographic affect. That punctum is time. Photographs make visible the passage of time and they mark our inability to halt its passage. This relation between photography and time is central to understanding how photography, and portrait photography in particular, is linked to mourning. In Camera Lucida, Barthes reads Alexander Gardner's 1865 portrait of Lewis Payne, a young man who was photographed in his cell while awaiting execution for attempting to assassinate Secretary of State W.H. Seward: "The photograph is handsome, as is the boy: that is the studium. But the punctum is: he is going to die." 39 Barthes quickly comes to see that all photographs make visible our being-towards-death. "I read at the same time: This will be and this has been; I observe with horror an anterior future of which death is the stake. By giving me the absolute past of the pose (aorist), the photograph tells me death in the future." 40

The photographs that make up the "Faces and Phases" series exploit the relation between photography and mourning to great effect. All the photographs in the series are shot in black-and-white; almost all the subjects face the camera, "returning" the viewer's gaze; most are half-length portraits, and several depict only the head and shoulders of the subject. Each photograph is captioned with the name of the person portrayed, the place in which they were photographed, and the date the image

\footnotetext{
${ }^{35}$ Michel Foucault, Archaeology of Knowledge, 145.

${ }^{36}$ See Chambers, Untimely Interventions, 29. See also Chambers, Facing It (1998), for an excellent study of how writing the experience of living with and dying of AIDS tests the boundaries of autobiographical writing.

${ }^{37}$ Natasha Distiller's essay "Another Story" offers a critical reflection on the limits of and for lesbian experience within representation. Interestingly, Muholi refers to Distiller's argument in her discussion of her motivation for producing "Faces and Phases" and states: "I wanted to resist the heterosexual representation of lesbians through portraits" (Muholi, "Mapping Our Histories," 26).

${ }^{38}$ Barthes, Camera Lucida, 38.

${ }^{39}$ Ibid., 96.

${ }^{40}$ Ibid.
} 
was taken. The uniformity of the images indicates that they form part of a single body of work. The seeming regularity of the series also serves another end-it operates as a visual sign of a shared experience, of a community of being, and is a common practice in photography that aims to memorialize.

Muholi's artist's statement for "Faces and Phases" overtly articulates her desire to assert black queer presence in contemporary South Africa and frames that desire in relation to the ever-present threat of violence, both discursive and material. "It is important to mark, map and preserve our mo(ve)ments through visual histories for reference and posterity so that future generations will note that we were here." ${ }^{41}$ In her description of the work she intends the series to perform, Muholi writes: "Historically, portraits serve as memorable records for families and friends as evidence when someone passes. Faces express the persons, and Phases signifies the transition from one stage of sexuality or gender expression and experience to another." 42 Here, Muholi uses the term "passes" in the sense of "passed away" or "to die."

An analysis of the work that "Faces and Phases" performs also reveals how "passing" operates in another way, through these photographs that make visible the "passing away" of lesbians as a result of hate crimes and AIDS-related diseases and a form of "passing" between fixed-gendered positions. These portraits simultaneously permit these lesbian lives to "pass" into an archive of mainstream visual representation through their "hijacking" of the generic conventions of memorialization. Ross Chambers has developed this idea in relation to the work of gay writers who have testified to their experiences of living with and dying of AIDS. "Genrehijacking" makes use of established generic conventions to speak what culture has deemed unspeakable. In the case of Muholi's work in South Africa, what is unspeakable is both lesbian desire and loss. ${ }^{43}$ "Faces and Phases" mobilizes the conventions of memorial portrait photography to open a space for mourning and at the same time queers that space by juxtaposing images of the dead with multiple portraits of living queer subjects.

The question of what is at stake in this act of passing marks the fine line between passing as a strategy of survival, a mechanism that allows one to appear, and "passing away," becoming invisible as a queer subject through one's entry into the realm of the legible. This invisibility can be psychic, a metaphoric loss of subjectivity, and can take material form through the threat of murder that affects lesbian being everywhere in South Africa today. Muholi's artist's statement draws attention to the portraits of those who have died, but at the same time positions them among the portraits of the living. Here, the presence of the dead signals the precarious position of the living, and the living remind us of the subjectivity of the dead:

Phases articulates the collective pain we as a community experience due to the loss of friends and acquaintances through disease and hate crimes. Some of those who

\footnotetext{
${ }^{41}$ Muholi, "Faces and Phases."

${ }^{42}$ Muholi, "Mapping Our Histories," 27.

${ }^{43}$ Carolyn Hamilton discusses how art opens a space for what has been deemed unspeakable; see Hamilton,

"Uncertain Citizenship," 368.
} 


\section{K. Thomas}

participated in this visual project have already passed away. We fondly remember Buhle Msibi (2006), Busi Sigasa (2007), Nosizwe Cekiso (2009) and Penny Fish (2009): may they rest in peace. The portraits also celebrate friends and acquaintances who hold different positions and play many different roles within black queer communities - an actress, soccer players, a scholar, cultural activists, dancers, filmmakers, writers, photographers, human rights and gender activists, mothers, lovers, friends, sisters, brothers, daughters and sons. ${ }^{44}$

Positioning the portraits of the dead among those still living implies solidarity with the dead, a community that traverses the boundary between life and death. The rhetorical force of this pairing of the living and the dead powerfully refuses the dehumanization of black lesbians that led to the deaths of the women memorialized here. This positioning which insists on the relation between the living and the dead also means that we necessarily read each portrait in the series as haunted by the possibility of violence, rape and murder.

The photographs in the series of women who have died-Busi Sigasa, Penny Fish and Nosizwe Cekiso-make use of the recognizable codes of the obituary form; but read in relation to the other portraits in the series, these codes are undeniably queered. Witness the juxtaposition of "Nosizwe Cekiso, Gugulethu, Cape Town, 2008” with "Gazi T Zuma, Umlazi, Durban, 2010." What results is a form of queer memorializing that makes lesbian lives and deaths visible without sacrificing their queerness. It is the particularity of these deaths as lesbian deaths that Muholi will not allow to pass, even as they "pass" into the memorial structures of recognition. The photographs that make up "Faces and Phases" negotiate the line between passing and death, visibility and invisibility. For in these images, what we see is not "woman," and yet we cannot recognize these subjects as lesbians either; for a moment, in looking, the fixity of our gendered look cannot hold. ${ }^{45}$ "The structure of recognition has been suspended." 46

All that is thought to separate black lesbians from "human" subjectivity is simultaneously present and absent here. The photographs insist on the particularity of the black lesbians they portray at the same time as they insist on their samenessto other women, to other embodied subjects, to the human. Through these "straight" portraits, we bear witness to queer lives. Muholi's photographs move us through and beyond our perceptions of what lesbian subjectivity might be and at the same time challenge us to reconceptualize the bounds of what is thought to constitute the human. Must the passage between invisibility and visibility entail giving up queerness? In their complex defamiliarizing of the conventions through which we recognize the human, the portraits that constitute "Faces and Phases" suggest this does not have to be so.

Muholi's photographs claim a place for queer subjects in the field of visual art. Through this act of "claiming," her work testifies to the complexity of queer

\footnotetext{
${ }^{44}$ Muholi, "Faces and Phases."

${ }^{45}$ For a representative selection of images, see Muholi, "Faces and Phases: 9 July to 8 August 2009" (Brodie/ Stevenson Gallery), and Muholi, "Faces and Phases" (Michael Stevenson Gallery).

${ }^{46}$ Adams, Emptiness of the Image, 138.
} 
experience in post-apartheid South Africa and at the same time constitutes a demand for political recognition. Muholi's photographs, which bear witness to the experiences of lesbians who have been subject to hate crimes, as well as some of the responses her work has generated-like that of Xingwana-illuminate that this demand has yet to be met. ${ }^{47}$ The inclusivity of the South African Constitution is often the starting-point for debates about gay and lesbian rights in the country; however, as many of Muholi's photographs show, to be queer is still to be subject to multiple, and often violent, forms of erasure.

\section{ACKNOWLEDGEMENTS}

I would like to acknowledge the financial support of the National Research Foundation and of the Ford Foundation. I would like to thank Natasha Distiller, Carolyn Hamilton, Joan Hambidge, John Higgins and Coilin Parsons, all of whom read this paper at very short notice and offered me suggestions and encouragement; the participants in the Archive and Public Culture Research Initiative quarterly workshops and reading group; and Mona Hakimi, who provided research assistance at a critical time. The insights of the anonymous reviewers were both critical and generous. Andrew van der Vlies invited the paper into being. As always, Louise Green helped me to conceptualize and write this. Alastair Douglas makes it all possible. This is for Sophie Douglas, my brave wolf-child.

\section{REFERENCES}

Adams, Parveen. The emptiness of the image: Psychoanalysis and sexual differences. London: Routledge, 1996.

Barthes, Roland. Image, music, text. Trans. Stephen Heath. Glasgow: Fontana, 1977.

— Camera lucida: Reflections on photography. Trans. Richard Howard. New York: Farrar, Straus and Giroux, 1981.

Brundrit, Jean. A lesbian story. An exhibition project by Jean Brundrit, Self-published, 2008.

Butler, Judith. Gender trouble: Feminism and the subversion of identity. New York: Routledge, 1990. Chambers, Ross. Untimely interventions: AIDS writing, testimonial and the rhetoric of haunting. Ann Arbor: University of Michigan Press, 2004.

- Facing it: AIDS diaries and the death of the author. Ann Arbor: University of Michigan Press, 1998.

Distiller, Natasha. "Another story: The (im)possibility of lesbian desire." Agenda 63 (2005): 44-57.

Fabricius, Peter. SA fails to back efforts at UN to protect gays. Cape Times, June 23, p. 3, 2010.

Foucault, Michel. The archaeology of knowledge. Trans. A.M. Sheridan Smith. London: Routledge, 2002.

Gqola, Pumla Dineo. “Through Zanele Muholi’s eyes: Re/imagining ways of seeing black lesbians.”

In Zanele Muholi: Only half the picture, edited by Sophie Perryer. Johannesburg: STE, 2006. $82-9$.

\footnotetext{
${ }^{47}$ See for example the recent incident at the United Nations Human Rights Council in Geneva, where South Africa's representative Jerry Matjila objected to the inclusion of sexual orientation in a report on racism as to do so would be to "demean[s] the legitimate plight of the victims of racism" (Fabricius, "SA Fails to Back Efforts at UN to Protect Gays," 3).
} 


\section{K. Thomas}

Gunkel, Henriette. The cultural politics of female sexuality in South Africa. New York: Routledge, 2010.

Hamilton, Carolyn. "Uncertain citizenship and public deliberation in post-apartheid South Africa." Social Dynamics 35, no. 2 (2009): 355-74.

Lewis, Desiree. "Against the grain: Black women and sexuality." Agenda 63 (2005): 11-24.

Muholi, Zanele. Only half the picture: 29 March-29 April. Archived exhibition announcement and images. Cape Town: Michael Stevenson, 2005. http://www.michaelstevenson.com/ contemporary/exhibitions/muholi/muholi.htm, 2006a.

— Zanele Muholi: Only half the picture. Johannesburg: STE, 2006b.

. Mapping our histories: A visual history of black lesbians in post-apartheid South Africa. Self-published essay. http://www.zanelemuholi.com/writings.htm >, 2009.

- Faces and phases: 9 July to 8 August. Archived exhibition announcement and images. Johannesburg: Brodie/Stevenson. http://www.brodiestevenson.com/exhibitions/muholi/ index.htm, 2009.

- Faces and phases. Artist's statement and images. Cape Town: Michael Stevenson. http:// www.michaelstevenson.com/contemporary/exhibitions/muholi/facesphases.htm, 2010.

Ngcobo, Gabi. Introduction. In Zanele Muholi: Only half the picture, edited by Sophie Perryer. Johannesburg: STE, 2006. 4-5.

Pollock, Griselda. Encounters in the virtual feminist museum: Time, space and the archive. New York: Routledge, 2007. 1999.

Pratt, Minnie Bruce. Crime against nature. New York: Firebrand Books, 1990.

Sontag, Susan. On photography. New York: Penguin, 1979 [1973].

Van Wyk, Lisa. Xingwana: Homophobic claims "baseless, insulting." Mail and Guardian Online, March 5. http://www.mg.co.za/article/2010-03-05-xingwana-homophobic-claims-baselessinsulting, 2010.

Xingwana, Lulu. Address by the Minister of Arts and Culture, Ms Lulama Xingwana, MP, at the launch of Moral Regeneration Month, Polokwana, July 11. Department of Arts and Culture website. http://www.dac.gov.za/speeches/minister/2009/11Jull09Speech.html, 2009.

Xingwana, Lulu. Statement by Minister of Arts and Culture Ms Lulu Xingwana on media reports around the Innovative Women exhibition. Department of Arts and Culture website. http:// www.dac.gov.za/media_releases/2010/04-03-10.html, 2010. 